\title{
ANALISIS PELAKSANAAN PRAKTIKUM MENGGUNAKAN KIT IPA FISIKA DI SMP SE-KECAMATAN SOJOL KABUPATEN DONGGALA
}

\author{
Jamaluddin, Amiruddin Kade dan Nurjannah \\ e-mail: jamal_uddin2608@yahoo.com \\ Program Studi Pendidikan Fisika FKIP Universitas Tadulako \\ Jl. Soekarno Hatta Km. 9 Kampus Bumi Tadulako Tondo Palu - Sulawesi Tengah
}

\begin{abstract}
Abstrak - Telah dilakukan analisis terhadap 10 guru yang mengajar mata pelajaran IPA fisika kelas VII, kelas VIII dan IX di 10 SMP Negeri di se-kecamatn Sojol. Responden tersebut dipilih dari sekolah yang memiliki laboratorium dan tidak memiliki laboraturium IPA. Penelitian ini bertujuan untuk mengetahui pelaksanaan praktikum menggunakan KIT IPA fisika di Sekolah Menengah Pertama se-Kecamatan Sojol. Data penelitian ini dikumpulkan menggunakan kuisioner dan dianalisis secara deskriptif. Hasil penelitian ini menunjukkan bahwa persentasi pelaksanaan praktikum menggunakan KIT IPA Fisika sangat kurang. Berbagai hal yang menyebabkan rendahnya persentasi pelaksanaan praktikum ini yaitu :1) intensitas guru dalam mengikuti pelatihan laboratorium masih kurang, 2) ketersediaan alat dan bahan praktikum masih kurang, 3) materi pelajaran IPA cukup padat sehingga guru lebih memilih metode ceramah, 4) tujuan pembelajaran sulit dicapai melalui praktikum 5) dibutuhkan waktu khusus untuk persiapan sebelum praktikum dilaksanakan, 6) waktu pelaksanaan praktikum dalam jam tatap muka selalu tidak mencukupi,7) pemahaman guru terhadap konsep serta penggunaan alat-alat praktikum masih rendah, 8) guru sulit merancang LKS sendiri, 10) tidak adanya laboran dan laboratorium yang dapat membantu pelaksanaan praktikum IPA fisika.
\end{abstract}

Kata Kunci: Praktikum Fisika, Sekolah Menengah Pertama (SMP) se-Kecamatan Sojol dan KIT IPA Fisika

\begin{tabular}{ccr} 
I. & \multicolumn{2}{c}{ PENDAHULUAN } \\
Pendidikan & adalah & suatu \\
memanusiakan & manusia untuk mencapai
\end{tabular}
kemandirian dalam hidupnya. Dalam pendidikan formal, terdapat interaksi antara pendidik dan peserta didik yang sering disebut dengan proses belajar menagajar. Salah satu masalah yang dihadapi dunia pendidikan kita adalah lemahnya proses pembelajaran, anak kurang didorong untuk mengembangkan kemampuan berfikir. [1]

Mata pelajaran IPA yang dipelajari pada tingkat SMP meliputi fisika dan biologi, yang bertujuan untuk menanamkan keyakinan pada kebesaran tuhan Yang Maha Esa berdasarkan keberadaan, keindahan dan keteraturan alam ciptaannya. Memberi pemahaman tentang berbagai macam gejala alam, prinsip dan konsep IPA serta keterkaitan dengan lingkungan, teknologi, dan masyarakat.
Memberi pengalaman dan mengembangkan keterampilan, sikap dan nilai ilmiah. Memberi bekal pengetahuan dasar untuk melanjutkan pendidikan ke jenjang yang lebih lanjut pada peserta didik. [2]

Dalam proses pembelajaran IPA, guru dapat menggunakan berbagai macam metode pembelajaran yang dapat mengembangkan pengetahuan, pemahaman, keterampilan, dan nilai-nilai moral yang berkaitan dengan perkembangan ilmu pengetahuan dan teknologi dewasa ini. Untuk itu perlu dipilih metode pembelajaran yang sesuai dengan materi pembelajaran dan situasi dan kondisi fisik maupun mental siswa.

Salah satu metode pembelajaran IPA yang dapat menciptakan kondisi tercapainya hasil konsep keilmuan IPA dan komponen proses keilmuan IPA adalah dengan melaksanakan pembelajaran di laboratorium yang berupa 
praktikum. Kegiatan praktikum untuk SMP adalah kegiatan yang dilakukan untuk menemukan suatu konsep atau prinsip baru bagi siswa yang didasarkan pada konsep atau prinsip yang telah ada dan dirumuskan oleh para ahli. Apabila ditinjau dari segi siswa maka kegiatan praktikum ini adalah kegiatan untuk menemukan konsep atau prinsip, dan bila ditinjau dari segi ahli maka kegiatan ini adalah proses verifikasi konsep atau prinsip. Praktikum ini sendiri merupakan salah satu metode pembelajaran yang dapat menumbuh kembangkan rasa ingin tahu siswa, aktif, kreatif, inovatif, dan kejujuran ilmiah dalam menghadapi suatu masalah dalam realita kehidupan.

Kegiatan praktikum merupakan suatu kegiatan yang penting dalam PBM. Kegiatan ini dilaksanakan dalam rangka mendukung pencapaian tujuan pembelajaran yang telah ditetapkan dalam KTSP. Jika kegiatan praktikum tidak dilakukan sesuai KTSP, tentu beberapa tujuan pembelajaran tidak dapat dicapai oleh siswa dan ini dapat berpengaruh terhadap hasil belajarnya.

Menurut Hasruddin, \& Salwa secara garis besar praktikum sering dikaitkan dengan beberapa tujuan: (1) Untuk memotivasi siswa sebab kegiatan praktikum pada umumnya menarik bagi siswa sehingga mereka lebih termotivasi untuk belajar sains; (2) Untuk mengajarkan keterampilan dasar ilmiah; (3) Untuk meningkatkan pemahaman konsep; (4) Untuk memahami dan menggunakan metode ilmiah; dan (5) Untuk mengembangkan sikapsikap ilmiah. [3]

Berdasarkan hasil observasi di SMP seKecamatan Sojol, fakta yang terjadi dilapangan tidak sesuai seperti yang diharapkan. Pemanfaatan keberadaan laboratorium IPA di sekolah-sekolah tersebut ternyata minim. Berbagai hal menjadi kendalanya, antara lain fasilitas dalam laboratorium yang kurang memadai, latar belakang guru yang tidak semua dari pendidikan fisika serta guru yang kurang mengetahui cara menggunakan alat laboratorium, tidak adanya petugas laboratorium (laboran) yang berfungsi untuk mengelola laboratorium IPA tersebut. Kurang keterperhatikannya pengelolaan laboratorium IPA, menyebabkan Mereka hanya sebatas mengetahui teori, tanpa mengerti praktek ilmiahnya. Selain itu ada pula yang tidak memiliki sarana dan prasarana lengkap sebagai daya dukung keterlaksanaan kegiatan laboratorium IPA seperti pada alat-alat praktikum IPA fisika. Sehingga kegiatan praktikum IPA fisika belum terlaksana secara efektif.

Berdasarkan uaian di atas, maka rumusan masalah pada penelitian ini adalah "Bagaimanakah pelaksanaan praktikum menggunakan KIT IPA fisika di SMP seKecamatan Sojol Kabupaten? "

\section{METODE PENELITIAN}

Penelitian ini merupakan penelitian kualitatif yang datanya berupa fakta-fakta yang ada dan data yang diamati berupa kata-kata tertulis atau lisan dari orang-orang dan pelaku yang dapat diamati sehingga dalam penelitian ini digunakan pendekatan deskriptif kualitatif.

III. HASIL DAN PEMBAHASAN

Hasil

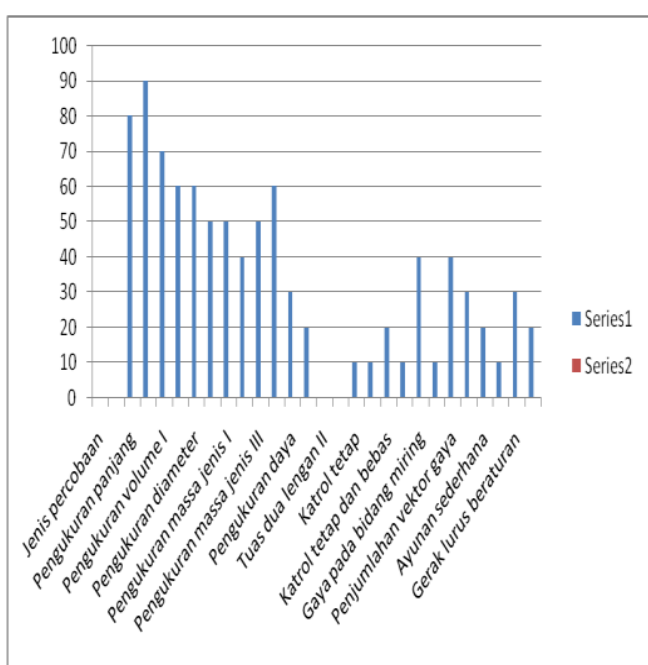

Gambar 1 Grafik Analisis Percobaan Menggunakan KIT mekanika yang Terlaksana 


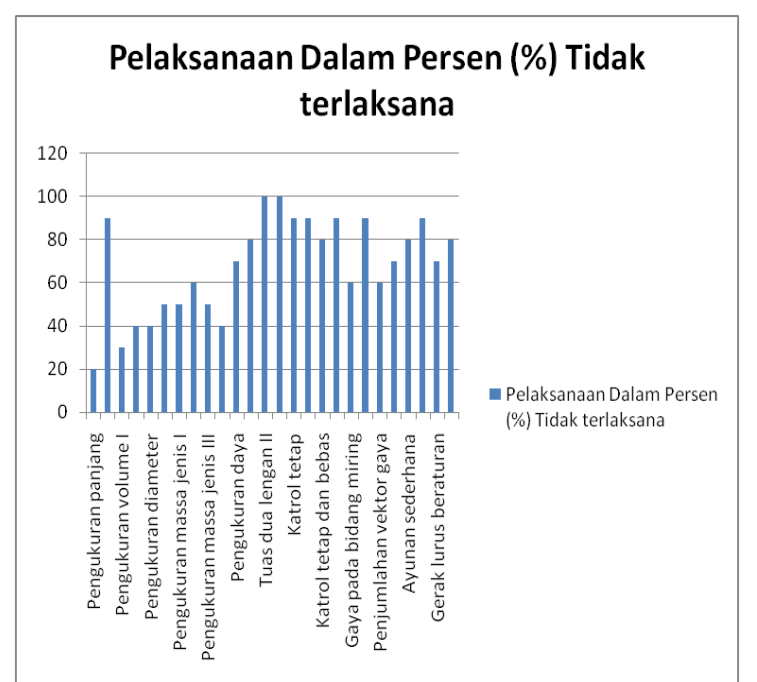

Gambar 2 Grafik analisis percobaan menggunakan KIT Mekanika yang tidak terlaksana

Bersumber pada grafik 1 dan 2 diketahui bahwa, dari sepuluh sekolah yang ada di Kecamatan Sojol pada percobaan menggunaka KIT mekanika yang pertama untuk percobaan pengukuran panjang yang melaksanakan yaitu sebesar $80 \%$ dan yang tidak melaksanakan sebesar $20 \%$. Percobaan pengukuran luas yang sekolah yang melaksanakan yaitu sebesar $90 \%$ dan yang tidak melaksanakan sebesar 10 $\%$. Percobaan pengukuran volume I yang melaksanakan sebesar $70 \%$ dan yang tidak melaksanakan sebesar $30 \%$. Percobaan volume II yang melaksanakan $70 \%$ dan yang tidak melaksanakan $30 \%$. Percobaan pengukuran diameter yang melaksanakan sebesar $60 \%$ dan yang tidak melaksanakan sebesar $40 \%$. Percobaan pengukuran massa dan percobaan pengukuran massa jenis I yang melaksanakan sebesar $50 \%$ dan yang tidak melaksanakan $50 \%$. Percobaan pengukuran massa jenis II yang melaksanakan sebesar 40 $\%$ dan yang tidak melaksanakan sebesar $60 \%$. Percobaan pengukuran massa jenis III yang melaksanakan sebesar $50 \%$ dan yang tidak melaksanakan sebesar $50 \%$. Percobaan pengukuran waktu yang melaksanakan sebesar $60 \%$ dan yang tidak melaksanakan sebesar 40 $\%$. Percobaan pengukuran daya yang melaksanakan $30 \%$ dan yang tidak melaksanakan sebesar $70 \%$. Percobaan tuas dua lengan I yang melaksankan sebesar $20 \%$ dan yang tidak melaksanakan sebesar $80 \%$. Percbaan tuas lengan II dan tuas lengan dua tunggal yang melaksankan $0 \%$ dan yang tidak melaksankan 100 \%. Percobaan katrol tetap dan katrol bebas yang melaksanakan sebesar $10 \%$ dan yang tidak melaksanakan $90 \%$. Percobaan katrol tetap dan katrol bebas yang melaksanakan sebesar $20 \%$ dan yang tidak melaksanakan $80 \%$. Percobaan sistem katrol yang melaksanakan sebesar $10 \%$ dan yang tidak melaksankan sebesar $90 \%$. Percobaan gaya pada bidang yang melaksankan sebesar $40 \%$ dan yang tidak terlaksana sebesar $60 \%$. Percobaan usaha pada bidang miring yang melaksanakan sebesar $10 \%$ dan yang tidak melaksanakan sebesar $90 \%$. Percobaan penjumlahan vektor gaya yang melaksanakan sebesar $40 \%$ dan yang tidak melaksankana sebesar $60 \%$. Percobaan gaya gesekan yang melaksanakan sebesar $30 \%$ dan yang tidak melaksanakan sebesar $70 \%$. Percobaan ayunan sederhana yang melaksanakan sebesar $20 \%$ dan yang tidak melaksanakan sebesar 80 $\%$. Percobaan kecepatan rata-rata yang melaksanakan sebesar $10 \%$ dan yang tidak melaksankan sebesar $90 \%$. Percobaan gerak lurus beraturan yang melaksanakan sebesar 30 $\%$ dan yang tidak melaksanakan sebesar $70 \%$. Dan percobaan gerak lururs berubah beraturan yang melaksanakan sebesar $20 \%$ dan yang tidak melaksanakan sebesar $80 \%$.

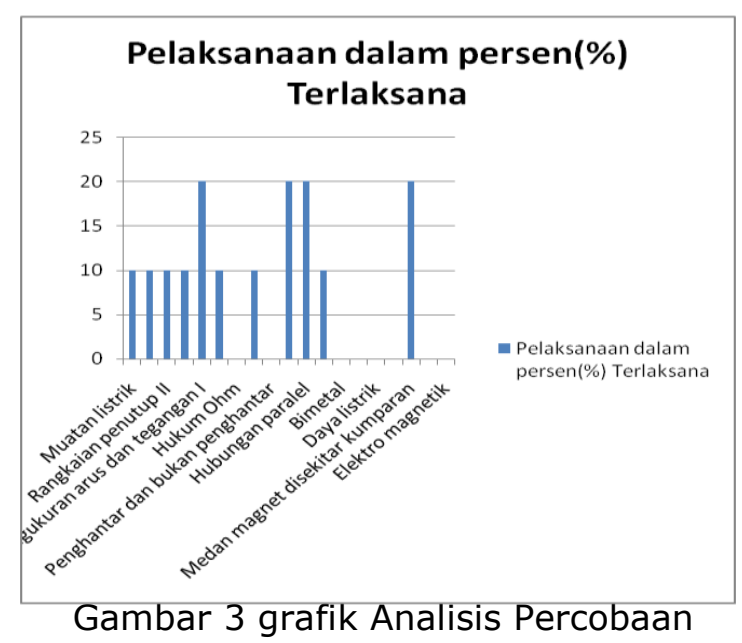

Menggunakan KIT listrik yang terlaksana 


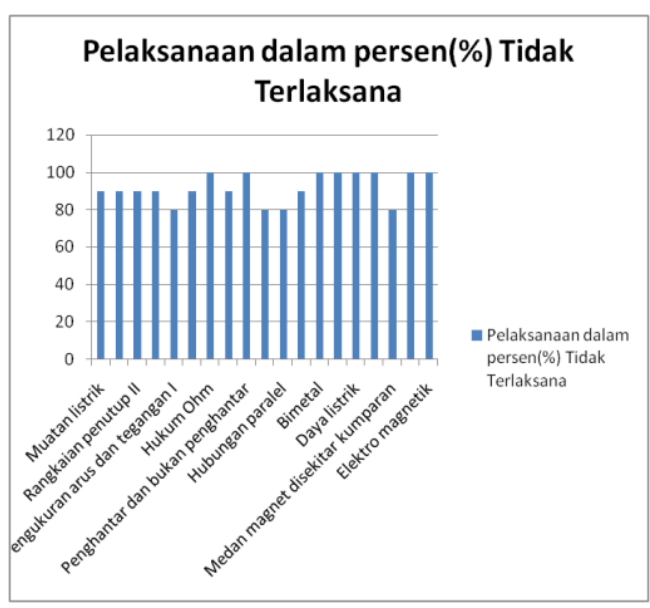

Gambar 4 grafik Analisis Percobaan

Menggunakan KIT listrik yang tidak terlaksana

Dari grafik 3 dan 4 dapat diketahui, percobaan menggunakan KIT listrik dari sepuluh sekolah yang ada di Kecamatan Sojol yang melaksankan dan yang tidak melaksankan pertama untuk percobaan muatan listrik yang melaksankan sebesar $10 \%$ dan yang tidak melaksanakan sebesar $90 \%$. Percobaan rangkaian penutup I, rangkaian penutup II dan rangkaian penutup III yang melaksankan sebesar $10 \%$ dan yang tidak melaksanakan sebesar $90 \%$. Percobaan pengukuran arus dan tegangan 1 yang melaksankan sebesar $20 \%$ dan yang tidak melaksanakan sebesar $80 \%$. Percobaan pengukuran arus dan tegangan 1I yang melaksankan sebesar $10 \%$ dan yang tidak melaksanakan sebesar $90 \%$. Percobaan hambatan suatu kawat penghantar yang melaksankan sebesar $10 \%$ dan yang tidak melaksanakan sebesar $90 \%$. Percobaan hubungan seri hambatan listrik dan percobaan hubungan paralel yang melaksankan sebesar $20 \%$ dan yang tidak melaksanakan sebesar 80 $\%$. Percobaan arus listrik menimbulkan panas yang melaksankan sebesar $10 \%$ dan yang tidak melaksanakan sebesar $90 \%$. Percobaan medan magnet disekitar kumparan yang melaksankan sebesar $10 \%$ dan yang tidak melaksanakan sebesar $90 \%$. Percobaan hukum ohm, penghantar dan bukan penghantar, bimetal, pengaman lebur atau sekering, daya listrik, medan magnet disekitar arus listrik, induksi magnetik, dan elektro magnetik yang melaksankan sebesar $0 \%$ dan yang tidak melaksanakan sebesar $100 \%$.

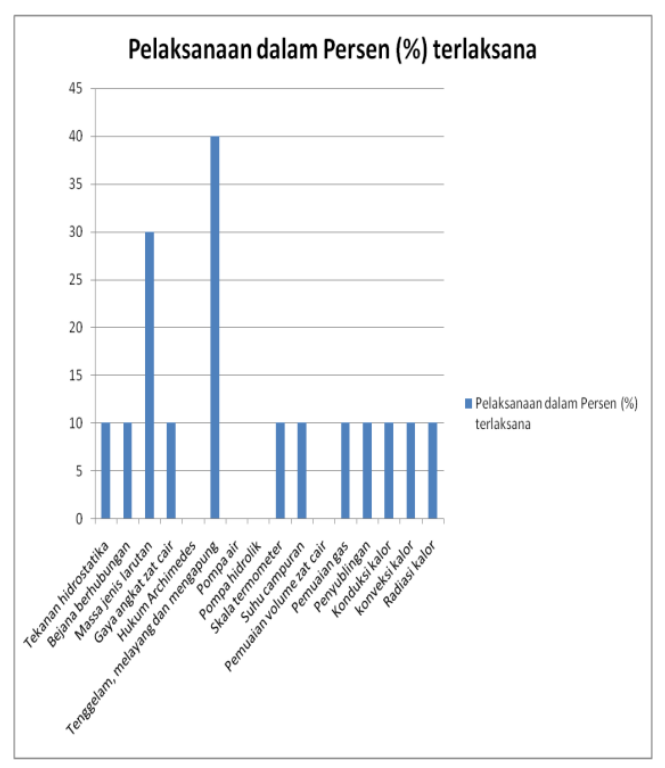

Gambar 5 grafik Analisis Percobaan Menggunakan KIT listrik yang terlaksana

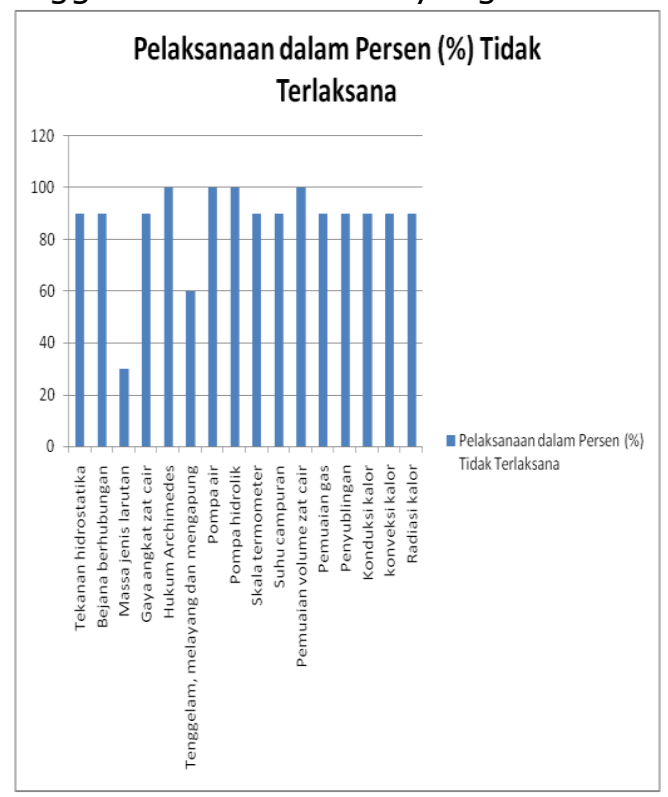

Gambar 6 grafik Analisis Percobaan

Menggunakan KIT hidrostatika yang tidak Terlaksana

Berdasarkan grafik 3 dapat dilihat bahwa, percobaan menggunakan KIT hidrostatika dari sepuluh sekolah yang ada di Kecamatan Sojol yang melaksankan dan yang tidak melaksankan pertama untuk percobaan tekanan hidrostatika dan bejana berhubungan yang melaksankan sebesar $10 \%$ dan yang tidak melaksanakan sebesar 90 \%. Percobaan massa jenis larutan yang melaksankan sebesar $30 \%$ dan yang tidak melaksanakan sebesar $70 \%$. Percobaan gaya angkat zat cair yang melaksankan sebesar 
$10 \%$ dan yang tidak melaksanakan sebesar 90 $\%$. Percobaan pompa air, pemuaian volume zat cair, dan pompa hidrolik yang melaksankan sebesar $0 \%$ dan yang tidak melaksanakan sebesar $100 \%$. Percobaan suhu campuran yang melaksankan sebesar $10 \%$ dan yang tidak melaksanakan sebesar $90 \%$. Percobaan pemuaian gas dan penyublingan yang melaksankan sebesar $10 \%$ dan yang tidak melaksanakan sebesar $90 \%$. Percobaan konduksi kalor, konversi kalor dan radiasi kalor yang melaksankan sebesar $10 \%$ dan yang tidak melaksanakan sebesar $90 \%$.

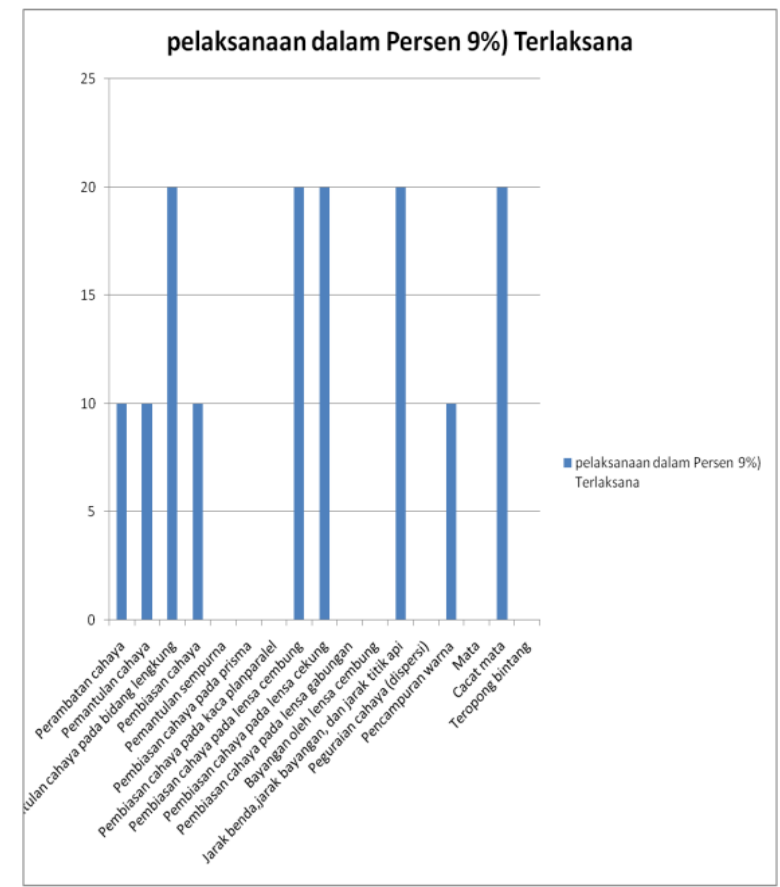

Gambar 7 grafik Analisis Percobaan Menggunakan KIT optik yang terlaksana

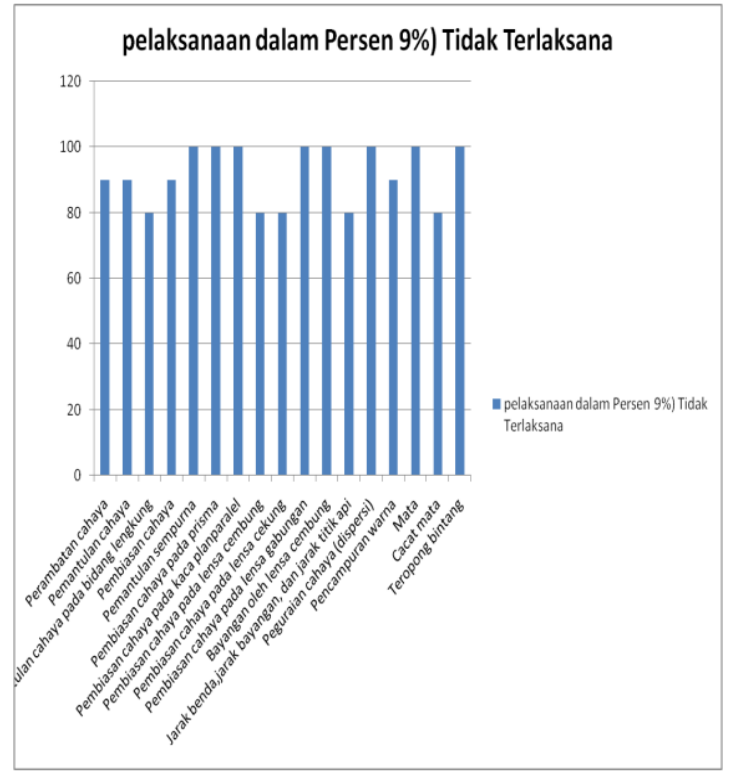

Gambar 8 grafik Analisis Percobaan Menggunakan KIT optik yang tidak terlaksana

Dari grafik 7 dan 8 dapat diketahui bahwa, dari sepuluh sekolah yang ada di Kecamatan Sojol pada percobaan menggunaka KIT optik yang pertama untuk percobaan perambatan cahaya dan pemantulan yang melaksankan sebesar $10 \%$ dan yang tidak melaksanakan sebesar 90 \%. Percobaan pemantulan cahaya pada bidang lengkung yang melaksankan sebesar $20 \%$ dan yang tidak melaksanakan sebesar 80 \%. Percobaan pembiasan cahaya yang melaksankan sebesar $10 \%$ dan yang tidak melaksanakan sebesar $90 \%$. Percobaan pemantulan sempurna, pembiasan cahaya pada prisma, dan pembiasan cahaya pada kaca planparalel yang melaksankan sebesar $0 \%$ dan yang tidak melaksanakan sebesar $100 \%$. Percobaan pembiasan cahaya pada lensa cembung dan pembiasan cahaya pada lensa cekung yang melaksankan sebesar $20 \%$ dan yang tidak melaksanakan sebesar $80 \%$. Percobaan pembiasan cahaya pada lensa gabungan yang melaksankan sebesar $0 \%$ dan yang tidak melaksanakan sebesar $100 \%$. Percobaan Jarak benda, jarak bayangan, dan jarak titik api yang melaksankan sebesar $20 \%$ dan yang tidak melaksanakan sebesar $80 \%$. Percobaan Peguraian cahaya (dispersi), mata dan teropong bintang yang melaksankan sebesar $0 \%$ dan yang tidak melaksanakan sebesar $100 \%$. Percobaan pencampuran warna 
yang melaksankan sebesar $10 \%$ dan yang tidak melaksanakan sebesar $90 \%$. Percobaan cacat mata yang melaksankan sebesar $20 \%$ dan yang tidak melaksanakan sebesar $80 \%$.

\section{Pembahasan}

\section{(1) KIT Mekanika}

Pada saat pelaksanaan praktikum dengan menggunakan KIT Mekanika guru mengalami beberapa kendala antara lain. Pada saat melaksanakan praktikum jumlah alat yang tersedia tidak mencukupi sehingga tidak semua kelompok praktikum menggunakan alat praktikum, siswa hanya diarahkan membuat kesimpulan berdasarkan apa yang diamati selama praktikum bukan menyusun laporan akhir praktikum, dan guru yang memberikan praktikum pada siswa bukanlah lulusan pendidikan fisika sehingga resiko terjadi miskonsepsi dalam konsep fisika sangat besar.

Adapun penyebab tidak terlaksananya pelaksnaan praktikum khususnya pada percobaan menggunakan KIT mekanika ialah hilangnya beberapa alat KIT sehingga menyebabkan tidak terlaksananya secara maksimal praktikum karena terlaksananya praktek tergantung dari ada tidaknya KIT IPA Fisika dan Guru IPA di Kecamatan Sojol ada yang memiliki latar belakang pendidikan bukan dari fisika bahkan ada juga yang hanya lulusan SMA.

Berdasarkan hasil wawancara yang telah dilakukan dengan guru maupun siswa yang ada di SMP Kecamatan Sojol jelaslah bahwa SMP se-kecamatan Sojol kekurangan KIT dan alat praktikum IPA fisika sehingga menyebabkan tidak terlaksananya secara optimal praktikum dan sedikitnya tenaga pendidik. Salah satu cara alternatif yang diberikan oleh guru apabilah tidak melaksanakan praktikum ialah dengan menampilkan animasi praktikum dan menjelaskan secara teori tanpa adanya kegiatan di laboratorium.

\section{(2) KIT Listrik}

Saat pelaksanakan praktikum dengan menggunakan KIT listrik, guru mengalami beberapa hambatan antara lain, pada saat melaksanakan praktikum jumlah alat yang tersedia tidak mencukupi sehingga siswa dibagi menjadi dua kelompok untuk menyesuaikan jumlah alat yang ada hal ini menyebabkan hanya beberapa siswa saja yang menggunakan alat praktikum dan siswa lainnya hanya memperhatikan sehingga menyebabkan siswa yang tidak menggunakan alat meluangkan waktunya diluar jam pelajaran yaitu saat jam istirahat, selain itu hambatan yang ditemukan di lapangan ialah siswa hanya diarahkan membuat laporan perkelompok adapun jika jam pelajaran berakhir siswa diberikan tugas rumah untuk menyelesaikan laporan praktikum sehingga berakibat siswa tak memahami keseluruhan tentang materi yang dipraktekkan, dan guru yang memberikan praktikum pada siswa bukanlah lulusan pendidikan fisika sehingga resiko terjadi miskonsepsi dalam konsep fisika sangat besar.

Tidak terlaksananya percobaan menggunakan KIT listrik khususnya untuk percobaan hukum ohm, penghantar dan bukan penghantar, bimetal, pengaman lebur atu sekering, daya listrik, medan magnet disekitar arus listrik, induksi magnetik dan elektro magnetik di SMP se-Kecamatan Sojol disebabkan karena tidak tersedianya alat praktikum serta jumlah guru yang yang tidak sesuai dengan jumlah siswa yang ada sehingga guru tidak mampu memberikan praktikum untuk semua kelas yang ada pada tiap sekolah di Kecamatan meskipun alat praktikum tersedia di sekolah ini

Berdasarkan hasil wawancara yang dilakukan dengan guru dan siswa jelaslah bawa SMP di kecamatan sojol kekurangan KIT listrik dan alat praktikum IPA fisika sehingga menyebabkan tidak terlaksananya secara optimal praktikum dan sedikitnya tenaga pendidik. Salah satu alternatif yang diberikan oleh guru untuk menggantikan alat yang tidak tersedia yaitu dengan merancang alat sederhana untuk melakukan praktikum.

\section{(3) KIT Hidrostatika}

Pada saat pelaksanakan praktikum dengan menggunakan KIT hidrosyayika guru mengalami beberapa masalah antara lain, saat melaksanakan praktikum ada beberapa alat yang hilang sehingga jumlah alat yang tersedia tidak sesuai dengan jumlah siswa yang ada, serta siswa tidak diarahkan membuat laporan 
akhir praktikum perkelompok setelah melaksanakan praktikum melainkan hanya dibimbing untuk membuat kesimpulan berdasarkan apa yang telah diamati pada saat praktikum dan guru yang memberikan praktikum pada percobaan fisika bukanlah guru yang memiliki latar belakang sebagai lulusan pendidikan fisika sehingga resiko terjadi miskonsepsi dalam konsep fisika sangatlah besar.

Adapun penyebab tidak terlaksanaya beberapa percobaan praktikum menggunakan KIT hidrostatika di SMP Kecamatan Sojol ini yaitu hilangnya beberapa alat KIT sehingga menyebabkan tidak terlaksanya secara maksimal praktikum karena terlaksananya kegiatan praktikum bergantung pada ketersediaan alat dan Guru IPA di SMP Kecamatan Sojol bukan dari pendidikan fisika yang menyebabkan banyak waktu yang dialokasikan untuk merangkai alat dikarenakan guru tidak mempunyai keterampilan dalam menggunakan alat.

Berdasarkan hasil wawancara yang telah dilakukan diketahui bahwa SMP di Kecamatan Sojol kekurangan KIT dan alat praktikum IPA fisika sehingga menyebabkan tidak terlaksananya secara optimal praktikum serta kurangnya kemampuan guru dalam menggunakan alat. Salah satu alternatif yang diberikan oleh guru apabila tidak melaksanakan praktikum ialah dengan menampilkan animasi dan simulasi dengan menggunakan media leptop.

\section{(4) KIT Optik}

Pada saat melaksanakan praktikum dengan menggunakan KIT optik guru mengalami beberapa hambatan, pada saat melaksanakan praktikum jumlah alat yang tersedia tidak mencukupi sehingga siswa dibagi menjadi dua kelompok untuk menyesuaiakan jumlah alat yang tersedia, dan alokasi waktunya yang kurang sehingga menyebabkan tidak terlaksananya semua kegiatan praktikum.

Adapun penyebab tidak terlaksananya pelaksnaan praktikum khususnya pada percobaan pemantulan sempurna, pembiasan cahaya pada prisma, pembiasan cahaya pada kaca planparalel, pembiasan cahaya pada lensa gabungan, bayangan oleh lensa cembung, dispersi, mata, dan teropong bintang dikarenakan alatnya tidak tersedia sehingga menyebabkan tidak terlaksananya secara maksimal praktikum karena terlaksananya praktek tergantung dari ketersediaan alat serta guru IPA di SMP Negeri 4 Sojol yang kurang mempunyai keterampilan dalam menggunakan alat sehingga tidak semua kelas diberikan praktikum walaupun KIT dan alat praktikum fisika tersedia di sekolah.

Berdasarkan hasil wawancara yang dilakukan jelaslah bahwa di Kecamatan Sojol kekurangan KIT dan alat praktikum IPA fisika sehingga menyebabkan tidak terlaksananya secara optimal praktikum. Salah satu alternatif yang diberikan oleh guru apabila tidak melaksanakan praktikum ialah dengan membuat alat seadanya dengan cara membuat alat praktikum sederhana.

Dari uraian di atas, didapatkan dua hal penting yaitu: guru IPA fisika SMP seKecamatan Sojol jarang melaksanakan praktikum dalam pembelajaran IPA fisika dan penyebab jarangnya mereka melaksanakan praktikum dapat dikelompokkan atas dua kelompok penyebab yaitu kompetensi guru itu sendiri dan dukungan fasilitas.

Hal ini sesuai pula dengan hasil penelitian Yenita, dkk [4] dan Hasruddin \& Salwa, [5] dimana penyebab guru jarang melakukan praktikum yaitu sebagai berikut: tidak tersedianya laboratorium IPA di sekolah, tidak tersedianya alat-alat praktikum IPA, guru tidak mempunyai latar belakang pendidikan IPA, sedikitnya waktu, ruangan yang terbatas, pemahaman guru yang kurang terhadap penggunaan laboratorium, dan tidak adanya laboran di laboratorium.

\section{KESIMPULAN}

Berdasarkan hasil penelitian yang telah dilakukan di SMP Negeri se-Kecamatan Sojol diketahui bahwa persentase terlaksananya praktikum menggunakan KIT IPA Fisika sangat rendah berbagai hal menjadi penyebabnya. Penyebab utama rendahnya persentase terlaksananya praktikum yaitu tidak tersedianya sarana dan prasarana serta guru 
yang kurang mengetahui cara penggunaan KIT IPA fisika.

\section{DAFTAR PUSTAKA}

[1] Sanjaya, Wina. (2008). Strategi Pembelajaran. Jakarta: Kencana Prenda Media Group.

[2] Depdiknas. (2004). Pedoman Khusus Pengembangan Silabus Berbasis Kompetensi. Jakarta: Depdiknas.

[3] Hasruddin, \& Salwa. (2012). Analisis Pelaksanaan Praktikum Biologi dan Permasalahannya di SMA Negeri Sekabupaten Karo. Jurnal Tabularasa PPS Unimed, 9, 17-32.

[4] Yenita, Mugisukmawati, \& Zulirfan. (2012). Hambatan Pelaksanaan Praktikum IPA Fisika yang Dihadapi Guru SMP Negeri Di Kota Pekanbaru. PMIPA FKIP Universitas Riau, 1-11.

[5] Hasruddin, \& Salwa. (2012). Analisis Pelaksanaan Praktikum Biologi dan Permasalahannya di SMA Negeri Sekabupaten Karo. Jurnal Tabularasa PPS Unimed, 9, 17-32. 